\title{
STRATIGRAPHIC ARCHITECTURE OF BEDROCK REFERENCE SECTION, VICTORIA CRATER, MERIDIANI PLANUM, MARS
}

\author{
LAUREN A. EDGAR, JOHN P. GROTZINGER, AND ALEX G. HAYES \\ Division of Geological and Planetary Sciences, California Institute of Technology, Pasadena, California 91125 USA \\ e-mail: ledgar@caltech.edu \\ DAVID M. RUBIN \\ US Geological Survey Pacific Science Center, Santa Cruz, California 95060 USA \\ STEVE W. SQUYRES AND JAMES F. BELL \\ Astronomy Department, Cornell University, Ithaca, New York 14853 USA \\ AND \\ KEN E. HERKENHOFF \\ US Geological Survey Astrogeology Science Center, Flagstaff, Arizona 86001 USA
}

\begin{abstract}
Aвstract: The Mars Exploration Rover Opportunity has investigated bedrock outcrops exposed in several craters at Meridiani Planum, Mars, in an effort to better understand the role of surface processes in its geologic history. Opportunity has recently completed its observations of Victoria crater, which is 750 $\mathrm{m}$ in diameter and exposes cliffs up to $\sim 15 \mathrm{~m}$ high. The plains surrounding Victoria crater are $\sim 10 \mathrm{~m}$ higher in elevation than those surrounding the previously explored Endurance crater, indicating that the Victoria crater exposes a stratigraphically higher section than does the Endurance crater; however, Victoria strata overlap in elevation with the rocks exposed at the Erebus crater. Victoria crater has a well-developed geomorphic pattern of promontories and embayments that define the crater wall and that reveal thick bedsets (3-7 m) of large-scale cross-bedding, interpreted as fossil eolian dunes. Opportunity was able to drive into the crater at Duck Bay, located on the western margin of Victoria crater. Data from the Microscopic Imager and Panoramic Camera reveal details about the structures, textures, and depositional and diagenetic events that influenced the Victoria bedrock. A lithostratigraphic subdivision of bedrock units was enabled by the presence of a light-toned band that lines much of the upper rim of the crater. In ascending order, three stratigraphic units are named Lyell, Smith, and Steno; Smith is the light-toned band. In the Reference Section exposed along the ingress path at Duck Bay, Smith is interpreted to represent a zone of diagenetic recrystallization; however, its upper contact also coincides with a primary erosional surface. Elsewhere in the crater the diagenetic band crosscuts the physical stratigraphy. Correlation with strata present at nearby promontory Cape Verde indicates that there is an erosional surface at the base of the cliff face that corresponds to the erosional contact below Steno. The erosional contact at the base of Cape Verde lies at a lower elevation, but within the same plane as the contact below Steno, which indicates that the material above the erosional contact was built on significant depositional paleotopography. The eolian dune forms exposed in Duck Bay and Cape Verde, combined with the geometry of the erosional surface, indicate that these outcrops may be part of a larger-scale draa architecture. This insight is possible only as a result of the larger-scale exposures at Victoria crater, which significantly exceed the more limited exposures at the Erebus, Endurance, and Eagle craters.
\end{abstract}

KEY wORDs: Mars, eolian, cross-bedding, stratigraphy

\section{INTRODUCTION}

Sedimentary rocks on Mars provide insight into past aqueous and atmospheric processes, climate regimes, and potential habitability. The Mars Exploration Rover Opportunity has investigated several impact craters in Meridiani Planum, Mars (Fig. 1), studying the exposed sedimentary rocks of the Burns formation ${ }^{1}$ in an effort to better understand the role of aqueous activity in its geologic history. In doing so, Opportunity discovered in situ evidence for an aqueous depositional environment at the Eagle, Endurance, and Erebus craters (Squyres et al. 2004b; Grotzinger et al. 2005, 2006; Squyres et al. 2006; Metz et al. 2009). Furthermore, these results also indicate that the stratigraphic architecture of sedimentary rocks on Mars is similar (though not identical) to that of Earth, indicating that the processes that govern facies deposition and alteration on Mars can be reasonably

\footnotetext{
${ }^{1}$ Note that the location and formation names used in this study are informal and have not been approved by the International Astronomical Union.
}

inferred through reference to analogous terrestrial depositional systems (Grotzinger et al. 2005).

As the mission progressed Opportunity explored increasingly larger outcrops over a greater spatial scope, and it became clear that both depositional and diagenetic processes acted regionally in extent (Squyres et al. 2009). Here, diagenesis refers to any low-temperature, low-pressure alteration after deposition, which may include weathering. One important interpretation is that most primary sedimentary bedforms - a key element in the sedimentology of the Burns formation - are not only regional in extent (found in many bedrock outcrops explored by the rover), they are also of very large magnitude. This is important because it facilitates a greater understanding of the processes controlling deposition as well as the scale of the depositional environment. The outcrop exposed at Opportunity's landing site in Eagle crater was only $35 \mathrm{~cm}$ thick (Squyres et al. 2004a). At Erebus crater, exposed outcrops were up to $5 \mathrm{~m}$ thick (Grotzinger et al. 2006, Metz et al. 2009), and at Endurance crater, the rover analyzed more than $7 \mathrm{~m}$ of stratigraphy (Grotzinger et al. 2005). These latter localities

Sedimentary Geology of Mars

SEPM Special Publication No. 102, Copyright ( 2012

SEPM (Society for Sedimentary Geology), Print ISBN 978-1-56576-312-8, CD/DVD ISBN 978-1-56576-313-5, p. 195-209. 


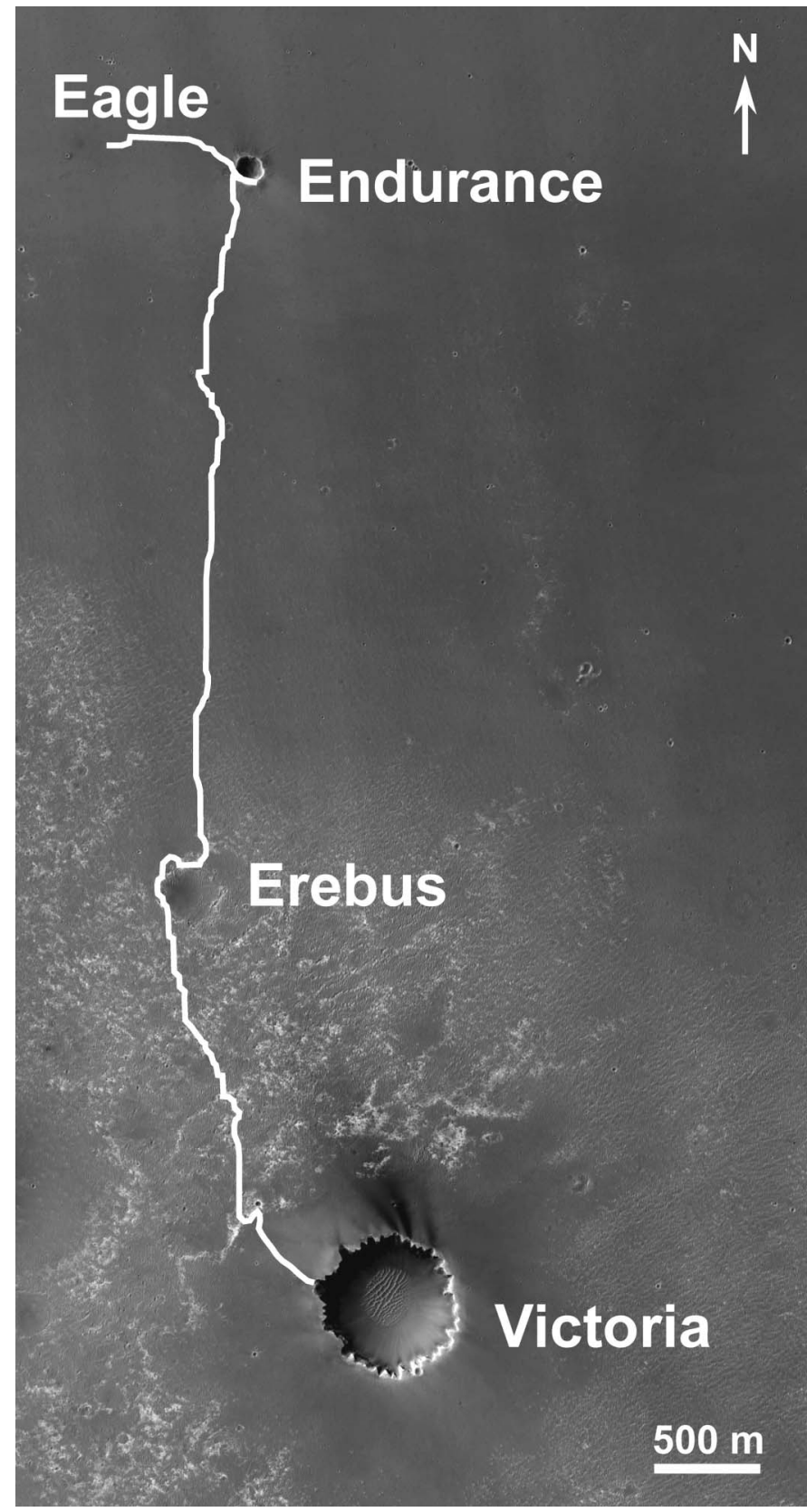

FIG. 1.-Opportunity traverse map as of Sol 952 plotted on HiRISE image (PSP_001414_1780). Victoria crater is approximately $6 \mathrm{~km}$ southeast of the original Opportunity landing site in Eagle crater. Sunlight illuminates scene from upper left. Image credit: NASA/ JPL/University of Arizona.

provided evidence for meter-scale cross-stratification. In contrast, outcrops at Victoria crater provide exposures of on the order of $15 \mathrm{~m}$ of true stratigraphic thickness, which permits analysis of larger scales of cross-stratification, and, thus, larger-scale primary bedforms can now be reconstructed.

Victoria crater lies $6 \mathrm{~km}$ southeast from the original Opportunity landing site in Eagle crater. At $\sim 750 \mathrm{~m}$ in diameter (Grant et al. 2008), it is the largest crater yet explored by Opportunity. Victoria crater offers the opportunity to test the existing models for bedrock formation and provides new insight into larger-scale sedimentary bedforms. This study examines the stratigraphy and eolian architecture along the ingress path at Duck Bay using data from the Microscopic Imager and Panoramic Camera to elucidate the structures, textures, and depositional and diagenetic events that formed and modified the Victoria bedrock. Several depositional and diagenetic hypotheses are explored, and a Reference Section exposed along the ingress path at Duck Bay is interpreted in the context of the regional geologic history.

\section{GEOLOGIC SETTING}

Rocks exposed in the region of the Opportunity landing site reveal a complex sedimentary history, involving eolian sediment transport and deposition, followed by episodic inundation by shallow surface water, evaporation, exposure, and desiccation (Squyres et al. 2004b; Grotzinger et al. 2005, 2006; Metz et al. 2009). The bedrock exposed at Eagle crater, combined with that in Endurance crater, reveals a stratigraphic thickness of approximately $7 \mathrm{~m}$, known as the Burns formation. The Burns formation refers to a sequence of well-sorted, moderately indurated sandstones, interpreted to be deposited by eolian and locally subaqueous processes (Grotzinger et al. 2005, McLennan and Grotzinger 2008). Represented by dune, sand sheet, and interdune facies, this formation records a progressive increase in the influence of groundwater and surface water during deposition (Grotzinger et al. 2005). This wetting-upward trend contrasts with the overall dryingupward trend as seen in the Erebus crater, at a slightly higher stratigraphic level (Metz et al. 2009). The series of outcrops explored by Opportunity at Meridiani Planum may comprise a full climatic cycle, from dry to wet to dry conditions, as one moves stratigraphically upward from the strata at Eagle crater through the strata at Erebus crater (Metz et al. 2009). After completing its exploration of the outcrops at Erebus crater, Opportunity set out to explore Victoria crater.

Victoria crater is a degraded simple crater at Meridiani Planum $\left(1.9483^{\circ} \mathrm{S}, 354.4742^{\circ} \mathrm{E}\right)$. Orbital images show that stratified rocks beneath the Meridiani plains lie disconformably on Middle to Late Noachian cratered terrains, indicating that the Meridiani plains might be as much several billion years old (Arvidson et al. 2003). Topographic measurements made by the Mars Orbiter Laser Altimeter indicate that the plains surrounding Victoria crater are $\sim 10 \mathrm{~m}$ higher in elevation than those surrounding the previously explored Endurance crater, indicating that Victoria crater exposes a stratigraphically higher section (assuming flat dip of strata). The outcrop exposed at Victoria crater may lie at the same elevation as the uppermost unit in Erebus crater, allowing for possible stratigraphic correlation between these two locations. Victoria crater has a scalloped rim produced by erosion and downhill movement of crater wall material. Most of the erosion is attributed to eolian processes, which are actively widening and filling the crater and elongating the crater across a WNW-ESE axis (Grant et al. 2008). The scalloped rim consists of a series of alcoves and promontories around the crater, exposing more than $10 \mathrm{~m}$ of wellbedded sedimentary rocks.

Prior to ingress at Duck Bay, Opportunity spent several months traversing the rim of the crater. Observations of outcrops at several promontories revealed thickly bedded units containing large-scale cross-stratification with bedsets of at least several meters in thickness (Squyres et al. 2009). Analysis of cross-bedding geometry indicates a paleo-wind direction oriented in a north-south direction (Hayes et al. 2011). A distinct light-toned band lines much of the upper rim of the crater. This band served as the basis for defining stratigraphic units (Squyres et al. 2009) named after prominent geologists and stratigraphers: Lyell, Smith, and Steno, in ascending order. Smith is the light-toned band, which is overlain by the Steno unit and underlain by the Lyell unit. Steno's upper contact is the base of the breccia 


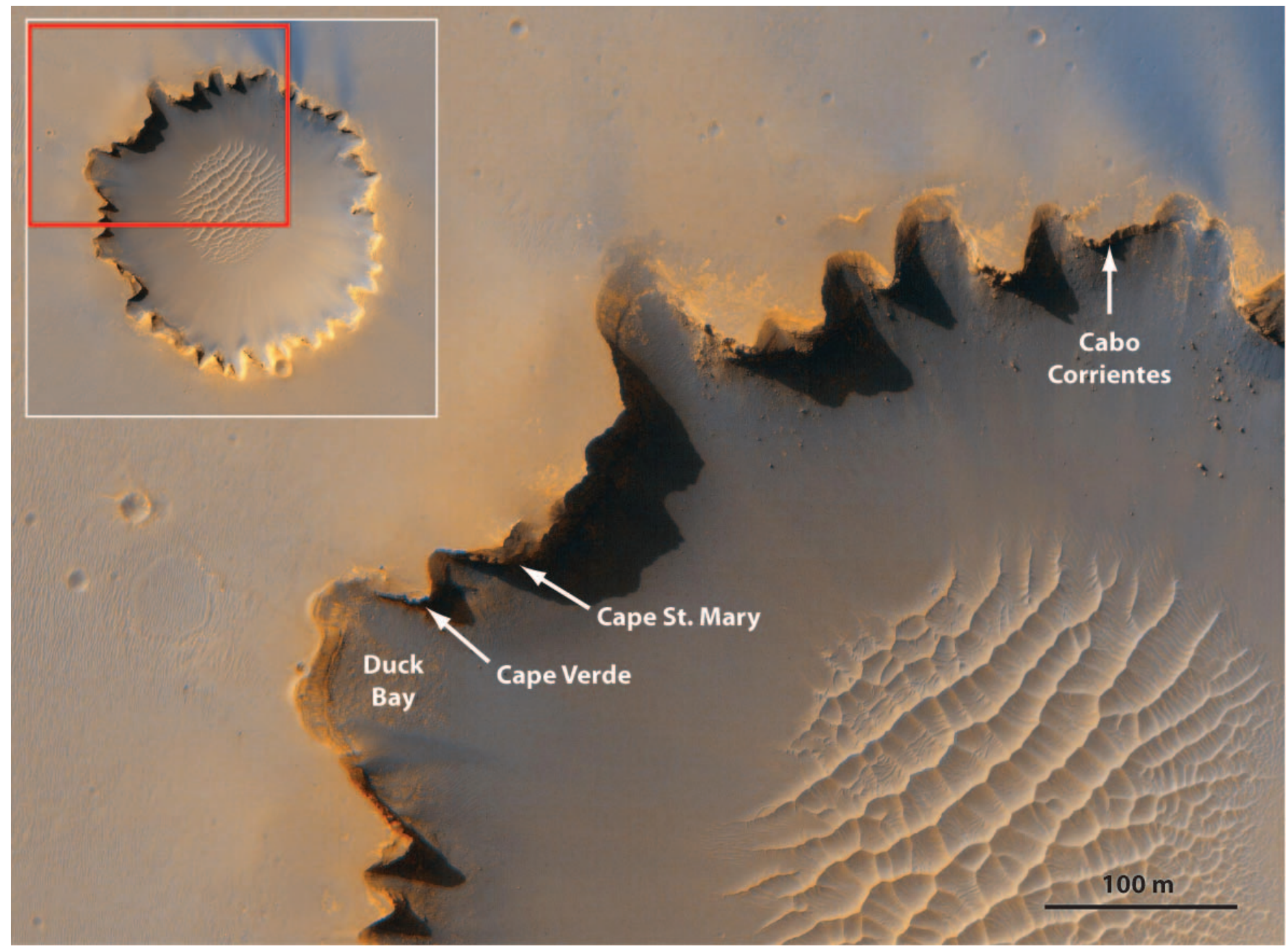

FIG. 2.—Duck Bay and nearby promontories Cape Verde and Cape St. Mary, seen in HiRISE image (TRA_000873_1780). Inset shows the crater's scalloped rim and the location of Duck Bay on the western margin of Victoria crater. Image credit: NASA/JPL/University of Arizona.

deposit generated during Victoria crater formation; Lyell's lower contact is not exposed, buried beneath the modern sands that fill the floor of the crater.

Duck Bay is located on the western margin of Victoria crater (between the promontories Cape Verde and Cabo Frio) with a slope shallow enough $\left(\sim 15-25^{\circ}\right)$ for Opportunity to ingress (Fig. 2). Detailed measurements of the three stratigraphic units were taken as Opportunity descended into the crater.

\section{METHODOLOGY}

\section{Instruments}

The stratigraphy and bedrock sedimentary structures at Duck Bay were observed by the Panoramic Camera (Pancam) and Microscopic Imager (MI). Pancam is a multispectral imaging system, which consists of two digital cameras mounted on the rover's mast $(1.5 \mathrm{~m}$ above the ground). Pancam is capable of both stereoscopic measurements (using parallax between the two camera "eyes," which are spaced $30 \mathrm{~cm}$ apart) and panoramic measurements (with the ability to image $360^{\circ}$ in azimuth and $\pm 90^{\circ}$ in elevation). Pancam has a focal length of $43 \mathrm{~mm}$ and a field of view of 1024 by 1024 pixels $\left(16^{\circ}\right.$ by $\left.16^{\circ}\right)$. Each of the two camera "eyes" includes a small eight-position filter wheel, allowing for multispectral mineralogical studies in the 400 to $1100 \mathrm{~nm}$ wavelength range (Bell et al. 2003).

The MI is a high-resolution imaging system mounted on the rover's "arm," or Instrument Deployment Device (IDD). The MI acts as both a microscope and a camera. With a camera body identical to those of Pancam, it also has a field of view of 1024 by 1024 pixels (Herkenhoff et al. 2003). The MI has a focal length of $20 \mathrm{~mm}$, a $\pm 3-\mathrm{mm}$ depth of field, and a field of view of $31 \mathrm{~mm}$ by $31 \mathrm{~mm}$ at a working distance of $63 \mathrm{~mm}$ (measured from the front of the lens to the object). MI produces images with a resolution of $30 \mu \mathrm{m} /$ pixel (Herkenhoff et al. 2003). As a result of highly variable topography, MI images are usually taken as a stack of images, with the IDD moving along a path normal to the surface, pausing every few millimeters to acquire an image (Herkenhoff et al. 2003).

The rover also has the capability to grind away dust and surface alteration to expose fresh rock surfaces for chemical and textural analyses. This is accomplished by the Rock Abrasion Tool (RAT). The RAT is positioned against a rock by the rover's arm and uses a diamond-tipped grinding wheel to remove a cylindrical area $4.5 \mathrm{~cm}$ in diameter and $0.5 \mathrm{~cm}$ deep (Gorevan et al. 2003). The RAT was designed to enhance petrologic textures of the fresh rock surfaces so 
TABLE 1.- Summary of MI observations.

\begin{tabular}{|c|c|c|c|c|}
\hline Unit & Target name & Sols acquired & Stack & RATed \\
\hline \multirow{2}{*}{ Steno } & Steno & 1313 & $1 \times 1 \times 5$ & brushed \\
\hline & Steno & 1320 & $1 \times 1 \times 10$ & RATed \\
\hline \multirow[t]{6}{*}{ Smith } & Smith_Hall_1 & 1322 & $1 \times 1 \times 18$ & none \\
\hline & Smith & 1332 & $2 \times 2 \times 5$ & none \\
\hline & Smith2 take2 & 1366 & $3 \times 1 \times 5$ & none \\
\hline & Smith2 & 1373 & $2 \times 2 \times 3$ & RATed \\
\hline & Smith_Lyell_Smith_side & 1409 & $4 \times 1 \times 5$ & none \\
\hline & Smith_Lyell_Smith_side & 1414 & $1 \times 1 \times 5$ & none \\
\hline \multirow[t]{4}{*}{ Lyell } & Lyell_1 & 1384 & $2 \times 2 \times 14$ & none \\
\hline & Lyell_Buckland & 1435 & $1 \times 1 \times 1$ & RATed \\
\hline & Lyell_Buckland & 1436 & $1 \times 1 \times 4$ & RATed \\
\hline & Lyell_Exeter & 1443 & $2 \times 2 \times 14$ & none \\
\hline
\end{tabular}

* Joint 1 stall, observation was not completed.

that they could be viewed effectively using the MI (Gorevan et al. 2003). However, overuse issues ${ }^{2}$ (which resulted in approximately $60 \%$ of the RAT holes covered in RAT grindings) significantly degraded the quality of the MI images taken along the ingress path Reference Section. The presence of RAT grindings in the holes obscures some features, so caution must be used when evaluating MI images of RATed targets.

\section{Data Collection}

Opportunity began its ingress into Victoria crater on Sol 1293. After driving $11 \mathrm{~m}$ downslope into the crater at Duck Bay, making detailed stratigraphic measurements of the exposed outcrop, the rover drove laterally $\sim 20 \mathrm{~m}$ to investigate several scientific targets at the nearby promontory Cape Verde. At its closest approach to Cape Verde, Opportunity maintained an $\sim 10-\mathrm{m}$ stand-off distance. While detailed chemical and textural analyses could not be acquired at this distance, super-resolution imaging allowed substantial observations of the stratification geometry and textures exposed at the cliff face. On Sol

\footnotetext{
${ }^{2}$ Encoders are attached to each of the three RAT motors and provide precise position information with which to monitor the penetration process. Another wheel holds a set of spinning brushes to wipe away dust and grit so that the abraded material is moved outward to form a dust skirt around the RAT hole. However, as the mission progressed many times beyond its planned 90 -sol lifetime, problems associated with overuse have developed. On Sol 1045, the RAT grind motor encoder failed. The MER science and engineering team developed a way to run the RAT without this encoder feedback, but on Sol 1334, the RAT revolve motor encoder failed. This meant that the RAT tool would run without precise monitoring (without knowing its exact position). On Sol 1348, the team first noticed an issue with the brush spot. Rather than clearing the grindings out of the RAT hole, only a small portion of the hole was cleared, and much of the hole contained RAT grindings. This was attributed to running the brush in the opposite direction, which resulted in a reconfiguration of the brush bristles - rather than being in line with the grinding bit, the bristles were twisted and some aligned with the $\mathrm{z}$-axis, serving to erode material more than clear material out of the hole.
}

1607, Opportunity began its egress, following nearly the same route as it did during ingress and eventually exiting the crater on Sol 1634.

Opportunity acquired many Pancam and MI observations over the course of nearly 150 sols on its $11-\mathrm{m}$ traverse downslope. Three stratigraphic units were distinguished based on sedimentary structures, diagenetic textures, and color, as revealed in Pancam images. Pancam observations were made almost every sol. The MI provided additional information on small-scale textures and diagenetic features. The RAT was used to expose fresh surfaces in some of the IDD targets by grinding away the outermost several millimeters of rock. However, after Sol 1348, the motor encoder failure resulted in partial covering of RAT holes, which obscured some of the features of interest, so our quantitative survey of diagenetic textures used only un-RATed images. Tables 1 and 2 summarize the key MI and Pancam observations of the rock units and the sols on which they were acquired.

\section{Data Processing}

Structural attitudes were obtained using Pancam stereo data. Range and topographic data can be derived from Pancam stereo image pairs, producing range maps out to $100 \mathrm{~m}$ or more from the rover (Squyres et al. 2003, Lewis et al. 2008). Occasionally, stereo images from the Navigation Camera (Navcam) also were used to produce range maps. Following the methods described by Lewis et al. (2008), linear segments along bedding planes were traced manually, and the corresponding topographic data were extracted. The natural curvature of the crater in the horizontal direction provided constraints on the three-dimensional geometry. A best-fit plane was calculated for each segment, and mathematical criteria ensured that the layers were well fit by a plane. Following the method of Lewis et al. (2008), we determined principle component eigenvalues to describe the variance in three orthogonal directions (the first and second components describe the plane, and the third component lies out of the plane). The variance in the first principal component was limited to less than $99 \%$, which excludes measurements for which the topography is too linear to determine the second dimension. Additionally, we excluded data for 
TABLE 2.-Pancam observations.

\begin{tabular}{llcc}
\hline Unit & Location & Sols on which most useful images were acquired & Sols on which additional images were acquired \\
\hline Steno & Duck Bay & $1319,1335,1338,1353,1363,1385$ & $1302,1305,1315,1316,1318,1320$, \\
\multirow{2}{*}{ Smith } & Duck Bay & $1332,1335,1337,1349,1350,1351,1334,1339,1377$ \\
& & $1353,1366,1374,1385,1426$ & $1321,1333,1338,1344,1348,1371$, \\
Lyell & Duck Bay & $1385,1423,1426,1432,1433,1438,1465$ & 1377,1390 \\
& Cape Verde & $952,970-991,1006,1329,1342,1356,1487$, & $1398,1419,1425,1428,1511,1512$ \\
& & $1574-1576,1579-1580,1581$ & $1329,1342,1346,1349,1358,1457$, \\
& & & $1472,1473,1487,1570,1572$, \\
\end{tabular}

which the ratio of the variance described by the second principal component to that of the third was greater than 15 to ensure that the planar fit was significantly larger than the out-of-plane error. Strike and dip values were then calculated from the best-fit plane. The stratigraphic thicknesses reported below are true thickness, corrected for a few degrees of westward dip, obtained using the methods described above.

Super-resolution images exposed fine details in targets that the rover was unable to reach. Super resolution is a method of combining information from a series of slightly offset images to produce a single image of the scene at higher resolution (Bell et al. 2006). The camera acquires 15 to 20 images in rapid succession at slightly offset pointings, and coregistration is performed. The images are first forward-mapped into high-resolution scratch space, and then a backpropagation algorithm is repeatedly applied to the scratch space, which iteratively improves the high-resolution image. Additional details are described in Bell et al. (2006).

\section{Simulations}

Several bedform simulations were run and cross-bedding geometries were compared to those observed in outcrop to test potential bedform morphologies and behaviors. We used a code that mathematically simulates bedforms and cross-bedding, which was developed by Rubin and Carter (2005). The code approximates bedform surfaces as sine curves. Bedform migration is created by displacement of the sine curves, height is produced by changing the amplitude, and superimposed bedforms can be modeled as combined sets of sine curves. The resulting block diagrams can be compared to the cross-bedding observed in rock outcrops in a variety of geometries.

\section{DUCK BAY SEDIMENTOLOGY AND STRATIGRAPHY}

Opportunity's ingress path in Duck Bay intersects three stratigraphic units named Lyell, Smith, and Steno, in ascending stratigraphic order (Fig. 3). These units, as observed along the rover ingress path, define the "Reference Section" for Victoria crater. The definitions and descriptions presented here form a set of observations that can be used for the purpose of comparison to other locations in the crater and for interregional correlations between craters. Changes in stratigraphic attributes relative to a defined Reference Section form the traditional basis for understanding lateral and temporal variations in depositional environment.

\section{Lyell Unit}

The lowermost unit, designated "Lyell," consists of $\sim 1.8 \mathrm{~m}$ of sulfate-rich sandstone (Squyres et al. 2009). Lyell is characterized by its darker tone, with well-defined pinstripe laminations. The average bed thickness is $\sim 2 \mathrm{~mm}$. It is a well-sorted, fine-grained sandstone, with meter-scale cross-bedding (Fig. 4E). Strike and dip measurements, calculated from Pancam stereo data, indicate that Lyell dips approximately $2^{\circ}$ to the west - away from the center of the crater. Measurements of cross-strata indicate dip directions to the southwest (Fig. 5).

The MI provided additional information on small-scale textures and diagenetic features, including abundant hematite-rich spherules and vugs indicative of crystal molds (Fig. 4F). Volumetric densities of spherules were estimated following the method of McLennan et al. (2005), using the relation $V=\left(\pi m l^{2} / 6 A\right)$, where $m$ is the number of spherules on a planar rock surface with area $A$ and $l$ is the mean spherule diameter. Spherules in Lyell range from $0.5 \mathrm{~mm}$ in diameter up to $1.5 \mathrm{~mm}$, with an average diameter of $0.90 \mathrm{~mm}$ (standard deviation $[S D]=0.27,378$ spherules). Lyell has more embedded spherules than does Smith or Steno, with a volumetric density of $1.04 \%(\mathrm{SD}=0.46 \%$, $\mathrm{n}=16$ frames). Lyell also contains abundant vugs, with tabularprismatic shape, and random orientations. The vugs in Lyell have a typical width of $\sim 0.25 \mathrm{~mm}$ and length of 1 to $2 \mathrm{~mm}$. While the vugs show similar geometry and similar proportions to those seen in the Eagle crater (Squyres et al. 2004b), they are an order of magnitude smaller. The vugs may contribute to the darker tone of this unit, helping to trap dark, likely basaltic sand grains (Squyres et al. 2009).

\section{Smith Unit}

The light-toned Smith unit directly overlies the Lyell unit. The contact between Smith and Lyell is gradational, and the darker tone and well-defined stratification of Lyell gradually fade upward. Smith is characterized by its smoother texture and lighter tone, which contrasts with its bounding units (Fig. 4C). The Smith unit at first appears massive, but images taken at low solar incidence angles reveal fine lamination, with lamina thicknesses similar to those in Lyell, on the order of $\sim 1$ to $2 \mathrm{~mm}$. Smith dips approximately $2^{\circ}$ to the west and has a thickness of $\sim 0.8 \mathrm{~m}$ (consistent with other exposures around the crater [Hayes et al. 2011]).

Smith has fewer spherules than does Lyell (Fig. 4D), with a volumetric density of $0.35 \%$ ( $\mathrm{SD}=0.15 \%, \mathrm{n}=14$ frames). Spherules in Smith have an average diameter of $0.73 \mathrm{~mm}(\mathrm{SD}=0.50 \mathrm{~mm} ; 162$ spherules). The lighter tone and poor expression of lamination of Smith indicates that Smith is recrystallized.

\section{Steno Unit}

Along the ingress path, a clear erosional contact distinguishes Smith from the overlying Steno unit. Inclined stratification in Smith is truncated by the lower bounding surface of Steno. Strike and dip measurements indicate that this truncation surface between Steno and 


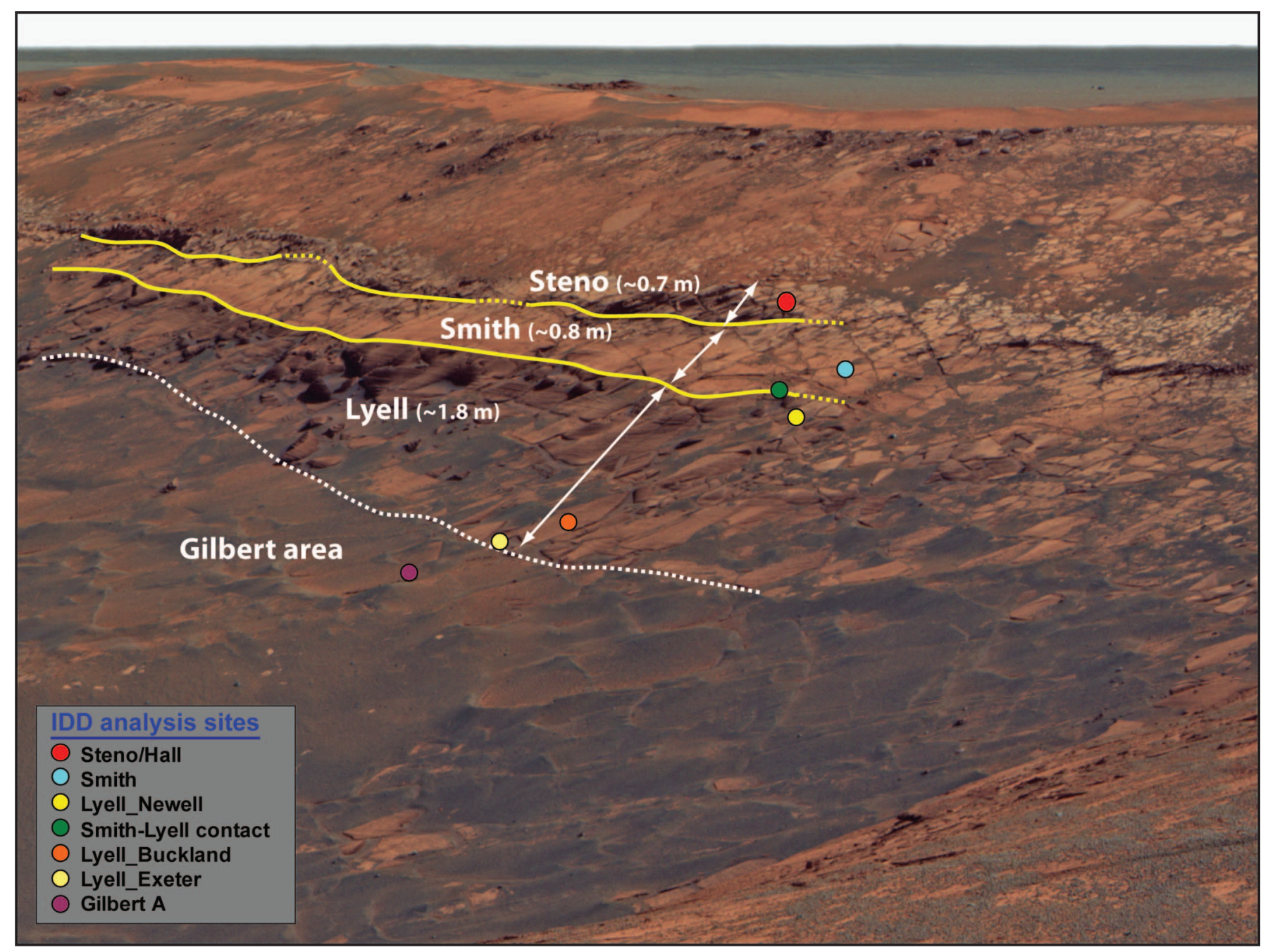

FIG. 3.- Ingress path as viewed from Cape Verde promontory (Cape Verde panorama, L257 false color mosaic, acquired during Sols 970-991). Three distinct units are visible in Duck Bay, named Lyell, Smith, and Steno, in ascending order. The Gilbert area corresponds with brecciated bedrock below the intact Lyell unit. Stratigraphic thicknesses (reported in parentheses) were derived from Pancam stereo images. Colored circles correspond to locations of detailed analyses by the MI as well as other tools on the IDD.

Smith has a dip of $\sim 10^{\circ}$ to the southeast. The beds above the erosional contact conform to the surface and dip predominantly to the southeast (Fig. 5). Measured as a true stratigraphic thickness, Steno consists of $\sim 0.7 \mathrm{~m}$ of sandstone. This measurement represents a minimum thickness due to erosion at the top of the unit, which coincides with the Amazonian weathering surface of Meridiani; the unit is overlain by impact breccia.

The Steno unit is composed of fine- to medium-grained sandstone, with well-defined laminae, on the order of $\sim 2 \mathrm{~mm}$ in thickness. Centimeter-to-meter scale cross-bedding is visible in places. In the ingress path, Steno shows a varied appearance when weatheredappearing as a more resistant step in topography (Fig. 4A). Often it has a rougher surface texture and has a darker tone, but sometimes it displays a smoother texture and lighter tone.

The spherules in Steno are relatively uniform in size and shape, with a mean diameter of $0.72 \mathrm{~mm}$ ( $\mathrm{SD}=0.19 \mathrm{~mm} ; 80$ spherules). Steno has more spherules than Smith but fewer than Lyell, with a volumetric density of $0.46 \%$ ( $\mathrm{SD}=0.1 \% ; \mathrm{n}=5$ frames). Steno also contains crystal-form vugs similar to those in Lyell, but less abundant.

\section{Chemostratigraphy}

In addition to observing the physical stratigraphy and diagenetic textures of the different rock units in Duck Bay, Opportunity made measurements of chemical and mineralogic compositions, which we will briefly summarize here. Locations of the chemical measurements are represented by colored circles in Figure 3, corresponding to labeled points in the stratigraphic column (Fig. 6). Overall, the rock compositions measured in Duck Bay fall within the range of rocks observed at previous craters studied by Opportunity and indicate that the rock units are composed of sulfates and silicates in slightly varying abundances (Mittlefehldt et al. 2008). Notable compositional differences include more $\mathrm{S}$ in Steno than was previously observed at Meridiani (Squyres et al. 2009) and more Zn in Smith (24\% higher) than in any other rock observed to date (Mittlefehldt et al. 2008). Smith 

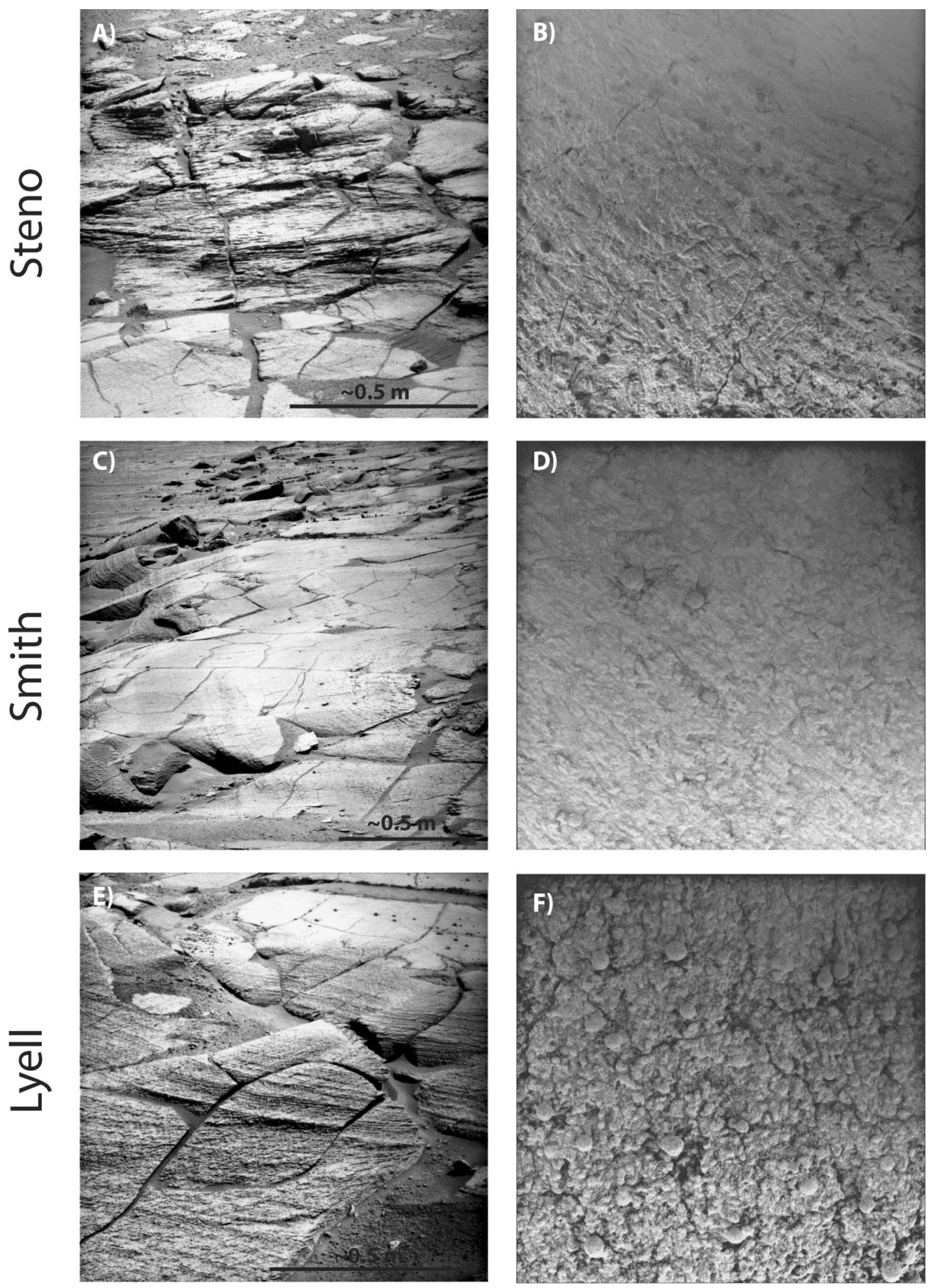

FIG. 4.-Pancam (left) and MI (right) images of Lyell, Smith, and Steno, documenting the large- and small-scale characteristics of the three different units in the ingress path. For scale, MI images are $31 \mathrm{~mm}$ on a side. MI images were taken with target fully shadowed. Note that the dark upper right corner of each MI image is the result of dust contamination of the MI optics. (A) In the ingress path Steno appears as a more resistant step in topography. (B) Steno consists of fine- to medium-grained sandstone with abundant hematite spherules. (C, D) Smith is characterized by its lighter tone and smoother texture at both scales. (E) Lyell is characterized by its darker tone (Smith is visible in the upper right portion of the image for comparison) and well-defined pinstripe laminations. (F) MI images of Lyell reveal numerous hematite spherules and vugs. Spherules in Lyell are larger and more abundant than those in Steno or Smith. 


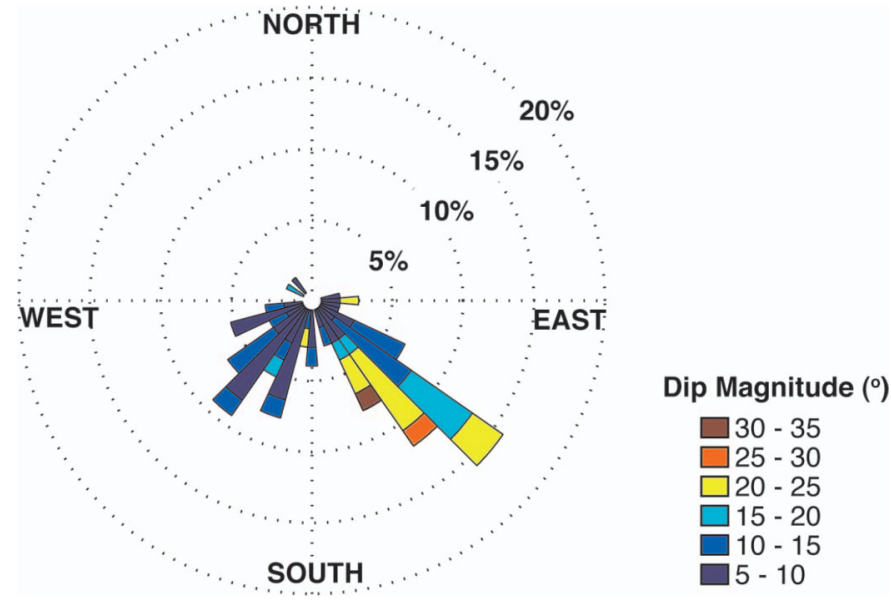

FIG. 5.- Rose diagram of bedding dips at Duck Bay, following the methods of Hayes et al. (2011). Colors correspond to dip magnitudes. Dip directions to the southwest correspond to measurements of cross-bedding in Lyell, while dip directions to the southeast correspond to measurements of cross-bedding in Steno. Bedding was not measured in Smith as a result of the poor expression of bedding.

and Lyell both show an increase in $\mathrm{Cl}$ content compared to StenoLyell reveals more than a factor of two increase in $\mathrm{Cl}$ compared to Steno (Mittlefehldt et al. 2008). The chemostratigraphic trends in Duck Bay are similar to those measured at Endurance crater-both sections reveal a decrease in $\mathrm{S}, \mathrm{Fe}$, and $\mathrm{Mg}$ down section and corresponding $\mathrm{Al}$ and Si enrichment (Squyres et al. 2009). The chemostratigraphic similarities between Endurance and Victoria may reflect the recurrence of depositional and diagenetic processes through time (Squyres et al. 2009), or they may reflect downward-penetrating diagenesis related to surface exposure (Amundson et al. 2008).

\section{CORRELATION TO CAPE VERDE}

The three stratigraphic units are visible around much of Duck Bay, but they cannot be directly correlated with the nearest promontory, Cape Verde (Fig. 7). A large area of brecciated bedrock separates the ingress path stratigraphy from that at the promontory, prohibiting the direct tracing of beds. Although the rover was unable to reach the cliff face at Cape Verde, detailed observations of several science targets were made through super-resolution imaging at the rover's closest approach ( $\sim 10-\mathrm{m}$ stand-off distance). The strata exposed at Cape Verde contain a light-toned band similar in thickness to that of Smith. Here it overprints well-laminated sandstone with low-angle crossbedding. Strata near the base of the cliff face have planar lamination to low angle cross-stratification, with dips that steepen upward in the upper half of the cliff face. Super-resolution imaging also reveals small climbing ripples superimposed on the larger dune cross-stratification (Fig. 7C).

The base of the cliff face contains a truncation surface (Fig. 7). Opportunity was unable to do a detailed analysis on the bedrock underlying this truncation surface, although a few exposures of bedrock indicate that the strata are inclined relative to those that overlie the surface (Fig. 7B). The truncation surface has a dip of $\sim 10^{\circ}$ to the southeast (Hayes et al. 2011); given that the erosional contact at the base of Steno also has a $\sim 10^{\circ}$ dip, it seems likely that these surfaces are related and likely represent scour by the same migrating bedform. This

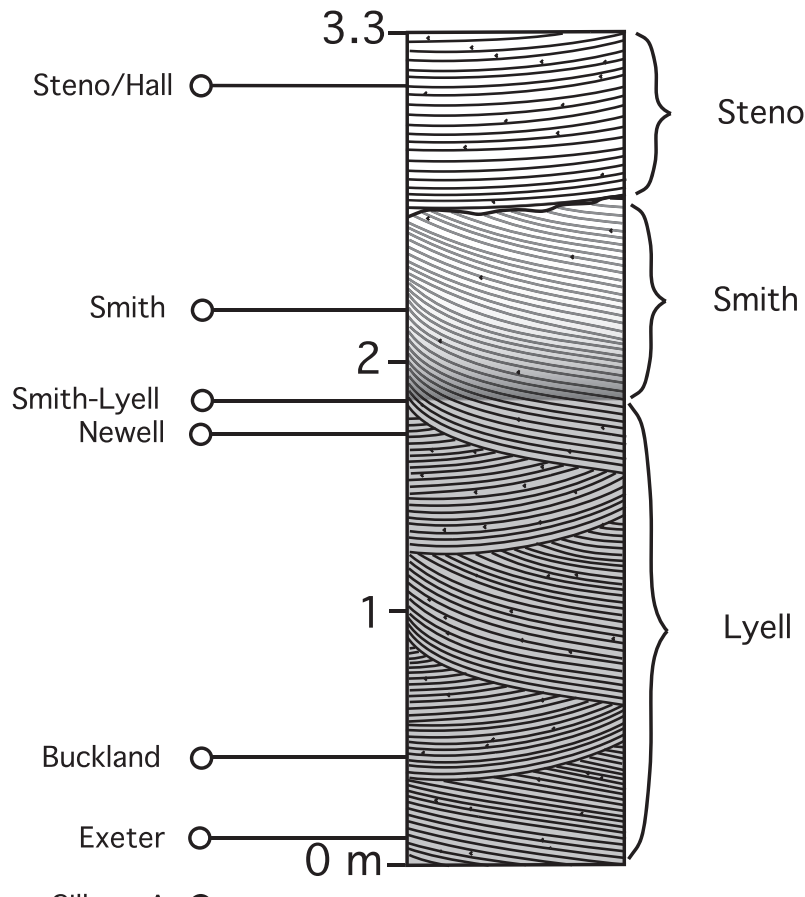

Eolian Dune Field
Cross Bedded Sandstone

Zone of Recrystallization Cross Bedded Sandstone

\author{
Eolian Dune Field \\ Cross Bedded Sandstone
}

Gilbert A O

FIG. 6.-Duck Bay stratigraphic column. Thicknesses are corrected for a $2^{\circ}$ dip to the west. Left-hand side shows locations of IDD targets (Gilbert A was sampled from a brecciated block below the intact unit Lyell). Smith is interpreted as a diagenetic band superimposed on cross-bedded sandstone. In the ingress path Smith is also bounded by an erosional contact with Steno. 

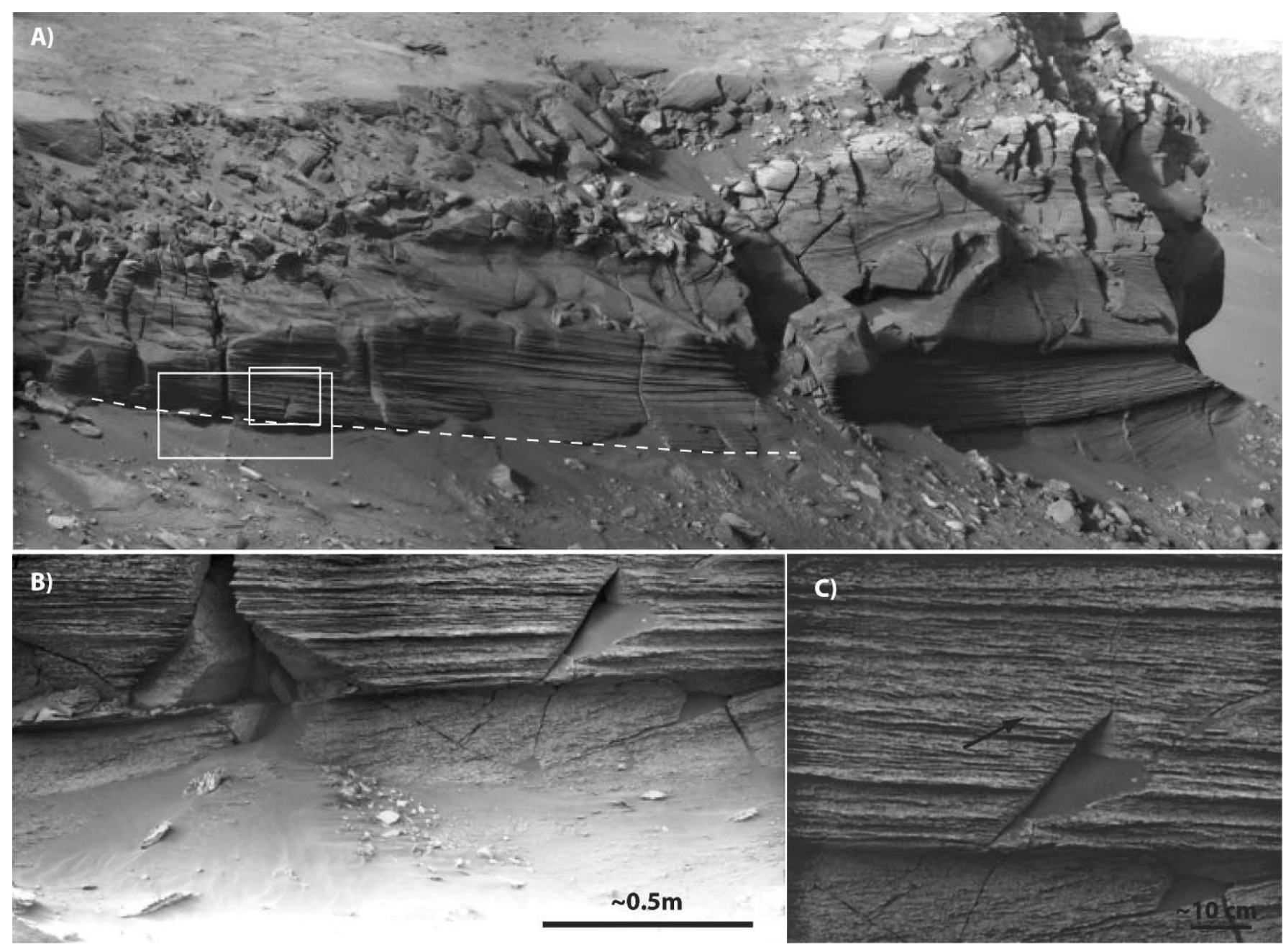

FIG. 7.-Cape Verde erosional surface. (A) White dashed line shows location of erosional surface at the base of Cape Verde, dipping approximately $10^{\circ}$ to the southeast (to the right in the above image) (Cape Verde super-resolution mosaic acquired during Sols 1342-1356). White boxes show locations of B and C. (B) Super-resolution image of erosional surface. Below the erosional surface, bedrock is exposed in the slope, with angled beds truncated by low-angle cross-stratification in the cliff face (Cape Verde super-resolution mosaic acquired during Sols 1574-1576). (C) Cross-strata represent ripples climbing toward the upper right portion of the image (arrow) (Cape Verde mosaic acquired during Sols 1579-1580).

is further supported by the observation that the two exposures of the truncation surface lie in the same plane.

\section{PALEO-DEPOSITIONAL ENVIRONMENT}

The primary sedimentary structures and diagenetic textures preserved in the ingress Reference Section at Victoria Crater define two facies. These include cross-bedded sandstone and planarlaminated to low angle cross-stratified sandstone. These facies require transport of sand under turbulent flows to generate bedforms ranging in scale from centimeters to meters. The dunes that deposited the crossstrata observed at Duck Bay and Cape Verde were probably an order of magnitude greater than $1 \mathrm{~m}$, likely on the order of tens of meters, as suggested by Rubin and Hunter (1982), as calculated from the preservation ratio [(mean thickness of preserved sets)/(mean topographical height)] for dunes (0.12) proposed by Paola and Borgman (1991) or inferred from the ratio of preserved set thickness to complete dune height that Mountney et al. (1999) observed for eolian dunes and cross-strata buried by lava. The abundance of planar, low-angle crossstratification, meter-scale cross-stratification, and pinstripe laminae (diagnostic of deposition by wind ripples (Hunter 1977) are most consistent with an eolian depositional environment. These observations and their inferred depositional environment are similar to what has been proposed previously for other locations studied by Opportunity.

However, in the interpretation of cross-stratified facies in Meridiani Planum, it is necessary to consider two alternative depositional models. Knauth et al. (2005) propose that the Meridiani strata represent an impact-induced base surge, and McCollom and Hynek (2005) propose that the strata were deposited during a volcanic base surge. These depositional models can be discounted on several grounds: (1) lack of evidence for contemporaneous sources of volcanism or impacts of sufficient size to produce base surge deposits (Squyres et al. 2006, McLennan and Grotzinger 2008); (2) spherules are dispersed relative to bedding (McLennan et al. 2005) rather than concentrated along bedding planes, as would be expected if they were accretionary lapilli 


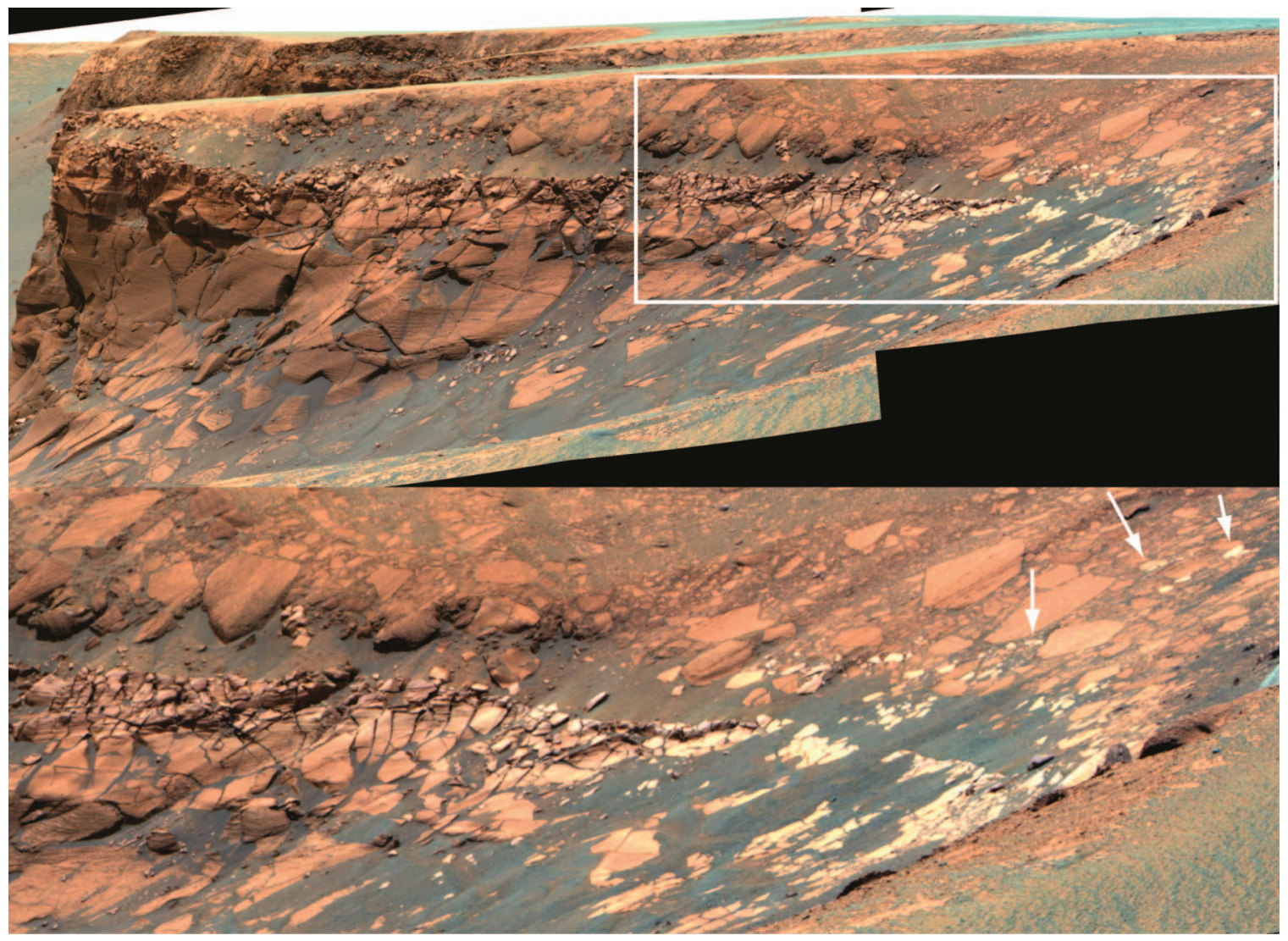

FIG. 8. - Cabo Corrientes false color mosaic acquired on Sol 1108. The false color stretch brings out subtle color differences in the outcrop, highlighting small blocks of the diagenetic band that are reworked into the impact breccia (white arrows point to several blocks). The diagenetic band ("Smith" as described in the ingress section) is interpreted to have formed after deposition but before the crater impact.

or iron condensation spherules; and (3) the scale of the cross-bedding exposed in Victoria crater (reconstructing to bedforms on the order of meters to tens of meters) has not been observed in any known base surge deposits. Therefore, the most probable explanation for the origin of cross-stratified facies at Victoria crater is that they were produced in an eolian depositional environment.

\section{Deposition and Diagenesis at Duck Bay}

Lyell and Smith, as defined in the Reference Section at Duck Bay, were likely deposited as part of the same eolian dune package, as evidenced by the gradational contact between them. Steno is a distinct stratigraphic unit marked by an erosional contact, which separates it from the light-toned Smith unit. While Smith is bounded by the erosional contact below Steno, its presence above the erosional contact at Cape Verde indicates that Smith crosscuts the primary bedding. This relationship is consistent with observations made at other exposures around the crater (Hayes et al. 2011). Small-scale diagenetic features indicate that Smith is recrystallized. Lyell shows the highest density of vugs and spherules, followed by Steno, and Smith shows the lowest density. The lighter tone, smooth appearance, and lack of vugs are the result of recrystallization. It is clear that Smith owes its unique identity to diagenesis, but the key question involves when that diagenesis occurred.

The observation that the diagenetic band has a low dip and is found near the rim of the crater raises hypotheses that it may be due to processes related to the Meridiani plains (intersection with the ground water table?), or it may be due to processes related to the crater impact (impact-induced melting of ice?). The fact that the diagenetic band is brecciated and in some outcrops reworked upward into the impact breccia (Fig. 8) indicates that the diagenetic band was not formed during or after the crater impact. The diagenetic band must postdate deposition of the eolian strata but predate the crater impact.

We also observe a low density of spherules in the diagenetic band. This may be explained by recrystallization prior to the precipitation of spherules. Early recrystallization of Smith may have eliminated pore space, so subsequent groundwater infiltration would not precipitate as many spherules in Smith as there are in Steno and Lyell.

\section{INTERPRETATION OF EOLIAN STRATIGRAPHIC ARCHITECTURE}

The recognition of cross-bedding geometry and bounding surfaces in ancient eolian deposits can be used to reconstruct wind direction, the nature of dune migration, and, ultimately, the sequence of events that produced the deposit. In turn, this may permit some understanding of changes in climate, sand supply, and possible subsidence. However, we are working with much more limited data than are available in most terrestrial studies of this nature, constrained by the few bedrock outcrops observed by the rover and by limited stereo coverage. Given the available data, we will consider a list of possibilities for the origin of the stratification exposed at Duck Bay and Cape Verde. 


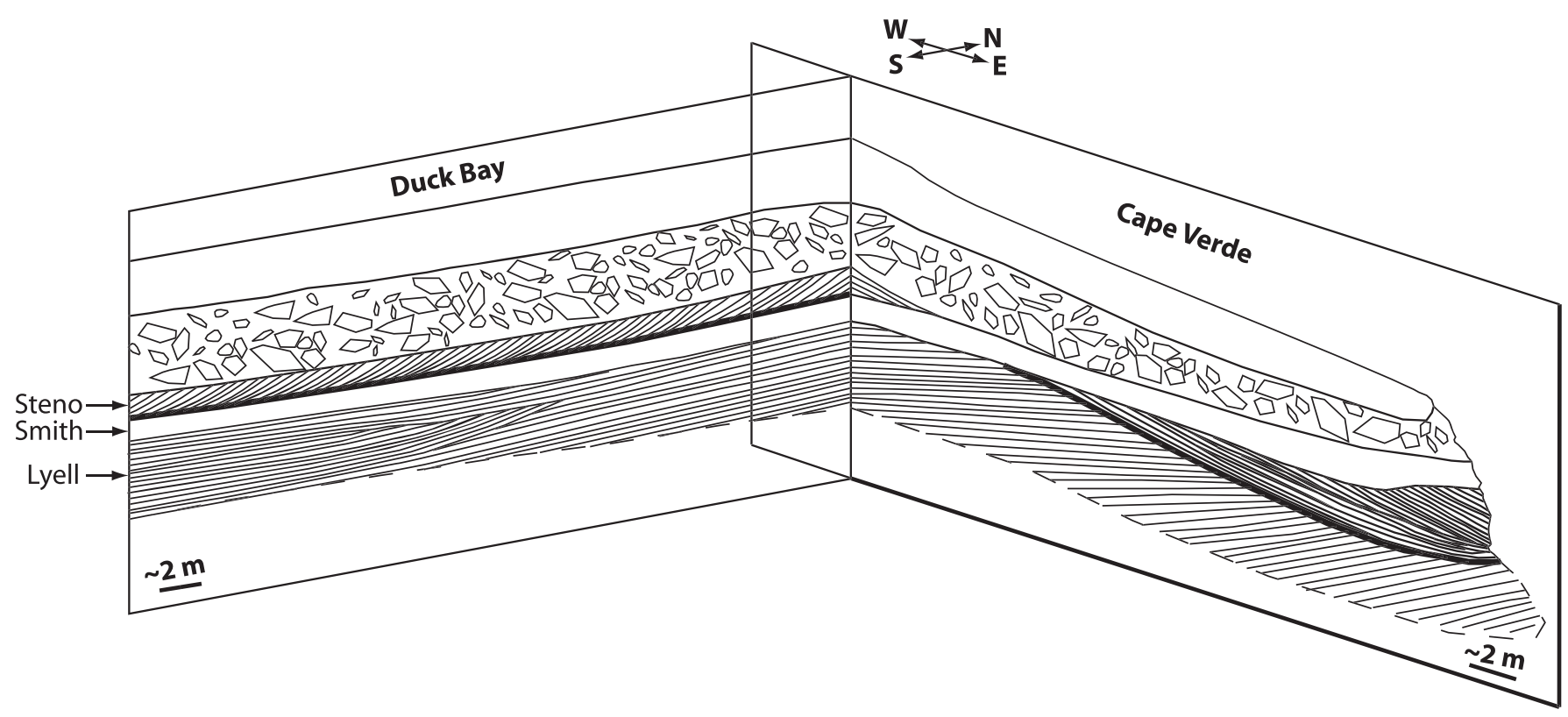

FIG. 9.- Schematic fence diagram depicting the three-dimensional geometry of the stratigraphy exposed at Duck Bay and Cape Verde. The diagenetic band Smith (white) crosscuts the erosional surface (heavy black lines). The erosional contact between Steno and Smith in the ingress path lies in the same plane as the erosional surface at the base of the Cape Verde cliff face. Note: the region at the intersection of these planes is inferred as a result of a lack of intact bedrock connecting Duck Bay and Cape Verde.

We begin by considering the truncation surface between Steno and Smith in the ingress path. As discussed above, we infer that the erosional contact at the base of Steno correlates with the erosional surface at the base of the Cape Verde cliff face. Although these surfaces lie at different elevations, they have a similar dip of approximately $10^{\circ}$ into the crater, and projection of this dip shows the potential continuity of the surface between elevations. The surface spans an area of least $300 \mathrm{sq} \mathrm{m}$ (limited by the few outcrops observed by the rover) and may represent an architectural element larger than the scale of the dune cross-bedding. In this case the erosional surface may be interpreted as a bounding surface produced by migration of dunes on a larger bedform (cf., Fryberger 1993). The compound bedform (smaller dunes migrating over a larger dune) may be termed a "draa." Figure 9 provides a reconstruction of the stratigraphy between the reference section along the ingress path and at Cape Verde. Note the crosscutting relationship of the diagenetic unit Smith and the position of the truncation surface.

Further consideration of cross-bedding geometry produces additional insight. Strata below the erosional surface, both at Duck Bay and at Cape Verde, dip to the southwest, while the strata above the surface dip to the southeast. This leads to two possible interpretations. The different dip directions may be interpreted as remnants of threedimensional sinuous crested dunes migrating southward. In this scenario, the strata dipping to the southwest would represent deposition on the west-dipping surface of the east side of a southward-migrating topographic depression. The strata dipping to the southeast would represent deposition on the east-dipping surface of the west side of a southward-migrating topographic depression (Fig. 10). Trough crossbedding produced by three-dimensional sinuous crested dunes is observed at nearby promontory Cape St. Mary, although the scale of the bedsets is much smaller (Hayes et al. 2011).

Alternatively, the different dip directions could be indicative of different dune-migration directions, from which paleo-wind directions maybe inferred. This interpretation is consistent with observations of terrestrial draas, which may contain reactivation surfaces representing the migration of dunes across a draa in different directions (McKee 1966). Work by Hayes et al. (2011) indicates that a pattern of reversing transport direction is observed at other locations around Victoria crater, and also with juxtaposition of cross-bedsets across larger-scale surfaces.

Figure 11 illustrates this shift in wind directions and the resulting cross-stratification. Using the model of Rubin and Carter (2005), we produce a large transverse bedform migrating from north to south, with superimposed bedforms that reverse migration direction. To model a reversal in wind direction, we allow the superimposed bedforms to reverse migration direction and asymmetry. While the superimposed bedforms reverse migration direction, their heights are decreased and then increased. The superimposed bedforms initially migrate from east to west, then reverse direction and migrate from west to east. The resulting stratification shows a subset of crossbeds at the base that dip to the southwest and an overlying subset of crossbeds that dip to the southeast (this is illustrated most clearly at the front corner of the block). The bounding surface that separates the two subsets dips to the south (note: in actuality, the bounding surface at Duck Bay and Cape Verde dips more to the southeast). A snapshot of the preserved crossstratification may reveal a bounding surface with cross-strata above and below the surface dipping in different directions, indicating a potential reversal in wind direction. This is analogous to the stratal geometry observed at the base of Cape Verde.

Given the available data, we are unable to distinguish between these two hypotheses. However, in both scenarios, the inferred net transport direction is roughly north to south, which is consistent with the inferred paleowind directions measured at other locations around the crater (Hayes et al. 2011). In the case of a large bedform with superimposed bedforms that reverse migration direction, the orientation of the erosional surface (rather than the cross-strata above the surface) may 


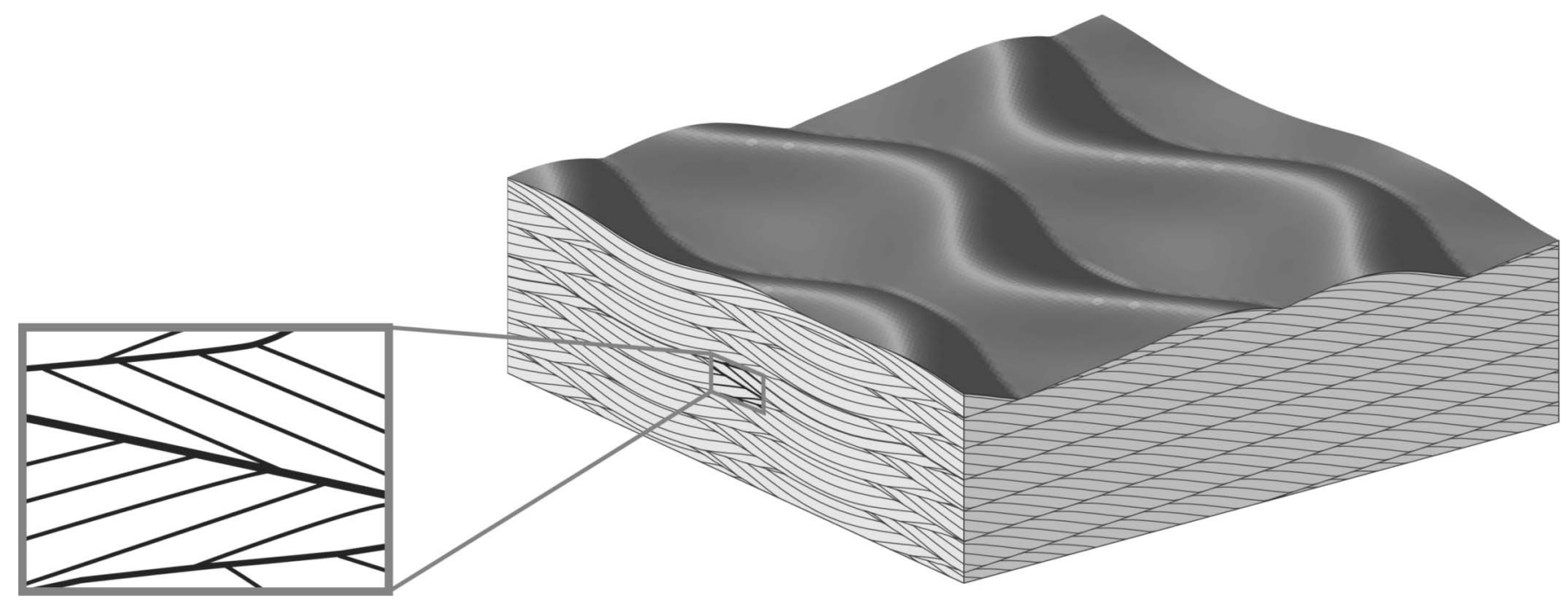

FIG. 10.-Three-dimensional sinuous crested bedforms, modified from Rubin and Carter (2005). The magnified box highlights a section perpendicular to the flow direction, showing a bounding surface (bold line) with strata above and below the bounding surface dipping in opposite directions. In the case of Cape Verde, the strata below the bounding surface may have been deposited on the east side of a southward migrating depression (strata below the bold line), whereas the strata above the erosional surface may have been deposited on the west side of a southward migrating depression (strata above the bold line).

serve as a better indicator of the local orientation of the bedform surface when it was formed. Rubin and Hunter (1983) have shown that in compound cross-stratification, the orientation of a bounding surface scoured by superimposed bedforms serves as a more accurate indicator of draa orientation than does the dip orientation of cross-strata (note that this result holds for situations in which the surface slope of the main bedform is relatively steep; $10^{\circ}$ is likely steep enough for this to be a better approximation than the crossbeds deposited by the superimposed bedforms). Cross-stratification-especially trough cross-stratification - can display a wide range of dip directions (up to $180^{\circ}$ ) even in a unidirectional wind; if only a small sample of these dip directions are measured - as is the case for Victoria crater - then the results might not be representative of the actual range of dips. In contrast, the dip direction of bounding surfaces scoured by superimposed bedforms is oriented roughly perpendicular to the draa brink and therefore serves as a more accurate indicator of the primary dune migration direction.

The Algodones dune field in southern California provides an excellent terrestrial example of a draa oriented roughly perpendicular-but not perfectly perpendicular - to the long-term resultant transport direction, with superimposed features driven by the secondary airflow (Havholm and Kocurek 1988). Havholm and Kocurek (1988) found that on the lee slope of a draa, surface airflow and the migration of superimposed bedforms is typically oblique or parallel to the draa brinkline, highlighting the importance of these bounding surfaces in reconstructing paleowind directions in the rock record. At Victoria crater, the erosional surface dips $10^{\circ}$ to the southeast. If this surface is a bounding surface scoured by a superimposed bedform, then the bounding surface may reflect the true orientation of the draa brinkline, migrating from northwest to southeast.

The erosional surface at Duck Bay and Cape Verde is also important in that it exposes a larger-scale bedform than had previously been seen in Meridiani Planum. If it represents the migration of dunes across a draa, then three orders of bedforms are observed at Duck Bay and Cape Verde: ripples, dunes, and draas. Draa deposits appear to be a common feature in the terrestrial rock record. Draas are typical of modern ergs (sand seas), often occurring in the centers of well-developed ergs, where sand cover is thickest (Wilson 1971, Havholm and Kocurek 1988). These conditions favor preservation, so draa deposits would be expected to be widespread in the rock record of eolian deposits on Earth (Havholm and Kocurek 1988) and in similarly arid environments on Mars. The three orders of bedforms observed at Cape Verde indicate that the ancient dune field glimpsed by Opportunity may have been a large sand sea (erg) (although the size of the reconstructed bedforms is somewhat smaller than that of terrestrial bedforms thought to have been deposited in eolian environments, such as the Navajo Sandstone [Rubin and Hunter 1982]).

The dunes in the center of Victoria crater provide a modern example of a dune field with multiple orders of bedforms, analogous to the ancient dune field preserved in outcrop. Pancam images reveal intersecting dunes in the center of the crater, with smaller superimposed dunes riding on the backs of the larger dunes (Fig. 12). The crater provides a confined basin for deposition, and complex wind patterns shape the sediment into star dunes. Modified secondary airflow builds smaller dunes on the backs of the larger dunes. Using a Digital Elevation Model (DEM) produced from stereo images from the orbiting High Resolution Imaging Science Experiment (HiRISE), we obtained estimates of dune heights ranging from 2 to $5 \mathrm{~m}$. While these are somewhat smaller than the estimated height of the ancient dunes preserved in the Victoria bedrock, this modern example indicates that the processes that governed ancient deposition are still acting on the modern Martian surface.

One feature that is notably absent from the bedrock outcrops at Victoria crater is evidence for brief periods of aqueous deposition, as observed at Eagle, Endurance, and Erebus craters (Grotzinger et al. 2005, Metz et al. 2009). Metz et al. (2009) suggest that as the rover has moved stratigraphically higher through Eagle, Endurance, and Erebus craters that it has observed a full climatic cycle, from dry to wet to dry. The bedrock outcrops at Victoria crater represent a stratigraphically higher section than that observed at Eagle and Endurance craters and may represent even drier climatic conditions and increased sediment 


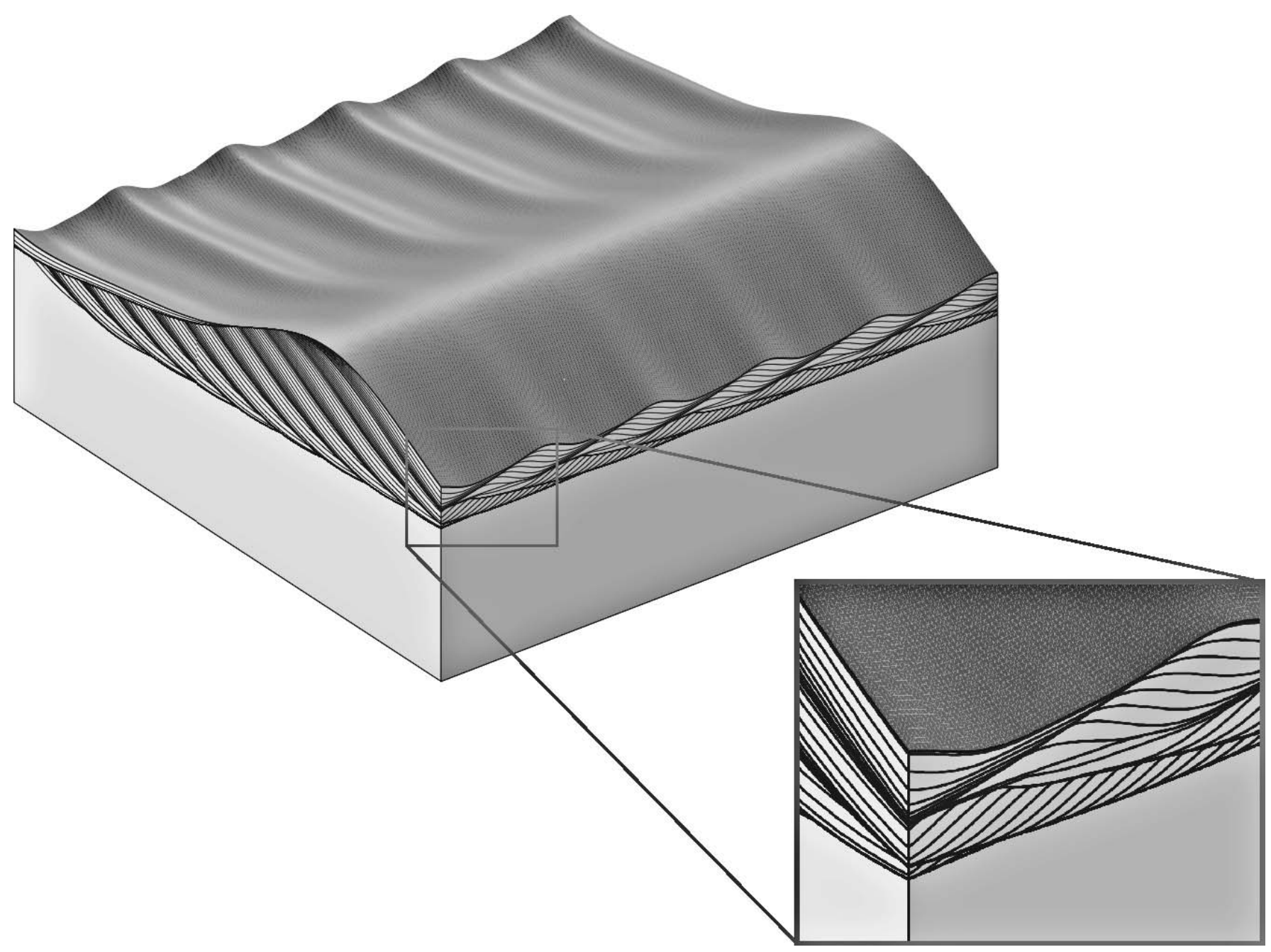

FIg. 11.-Depositional model for the stratal geometry at the base of Cape Verde, using code modified from Rubin and Carter (2005). Model illustrates the stratification produced by a large transverse bedform migrating from $\mathrm{N}$ to $\mathrm{S}$, with superimposed bedforms that initially migrate from $\mathrm{E}$ to $\mathrm{W}$, then reverse direction and migrate from $\mathrm{W}$ to $\mathrm{E}$. The resulting stratification shows a subset of crossbeds at the base that dip to the SW, an overlying subset of crossbeds that dip to the SE, and a bounding surface separating the two subsets that dips to the S. A snapshot of the preserved cross-stratification may reveal a bounding surface with cross-strata above and below the surface dipping in different directions, indicating a potential change in wind direction, analogous to the stratal geometry observed at the base of Cape Verde.

flux. This allogenetic hypothesis indicates that the conditions at a given point changed through time as a result of a changing climate. Alternatively, the lack of evidence for aqueous deposition may indicate lateral variations in time-equivalent facies. Victoria crater may expose strata from the center of a well-developed sand sea, whereas strata in Eagle and Endurance craters may represent a depression (or depressions) within the sand sea and may be more prone to the emergence of groundwater. In this autogenetic scenario, the degree of wetness of the depositional environment would depend more on local elevation relative to the water table, with changes in wetness controlled by the thickness of dry sand. The outcrop exposed in the Reference Section at Duck Bay appears to lie at a similar elevation to the uppermost unit exposed in Erebus crater. The upper unit of the Yavapai formation is interpreted to represent sandsheet/dune field facies (Metz et al. 2009). It is possible that the upper unit at Erebus represents the same period of deposition observed in the ingress path at Duck Bay, but the larger scale of the outcrops at Victoria crater exposes the stratal geometries consistent with construction of larger-scale eolian bedforms.

\section{CONCLUSIONS}

The strata exposed at Duck Bay and Cape Verde indicate deposition in an eolian dune environment, with further modifications though diagenesis. Images from the Pancam and MI reveal three distinct stratigraphic units in the Reference Section traced by the rover ingress path: Lyell, Smith, and Steno, in ascending order. In the Reference Section, Smith is interpreted as a secondary, diagenetic unit, which also is bounded by a primary, erosional contact, but elsewhere in the crater the diagenetic band crosscuts the primary stratigraphic surfaces. Evidence of the diagenetic unit reworked in the impact breccia indicates that Smith formed prior to the crater impact. Correlation with nearby promontory Cape Verde reveals that there is an erosional surface at the base of the cliff face that likely corresponds to the 


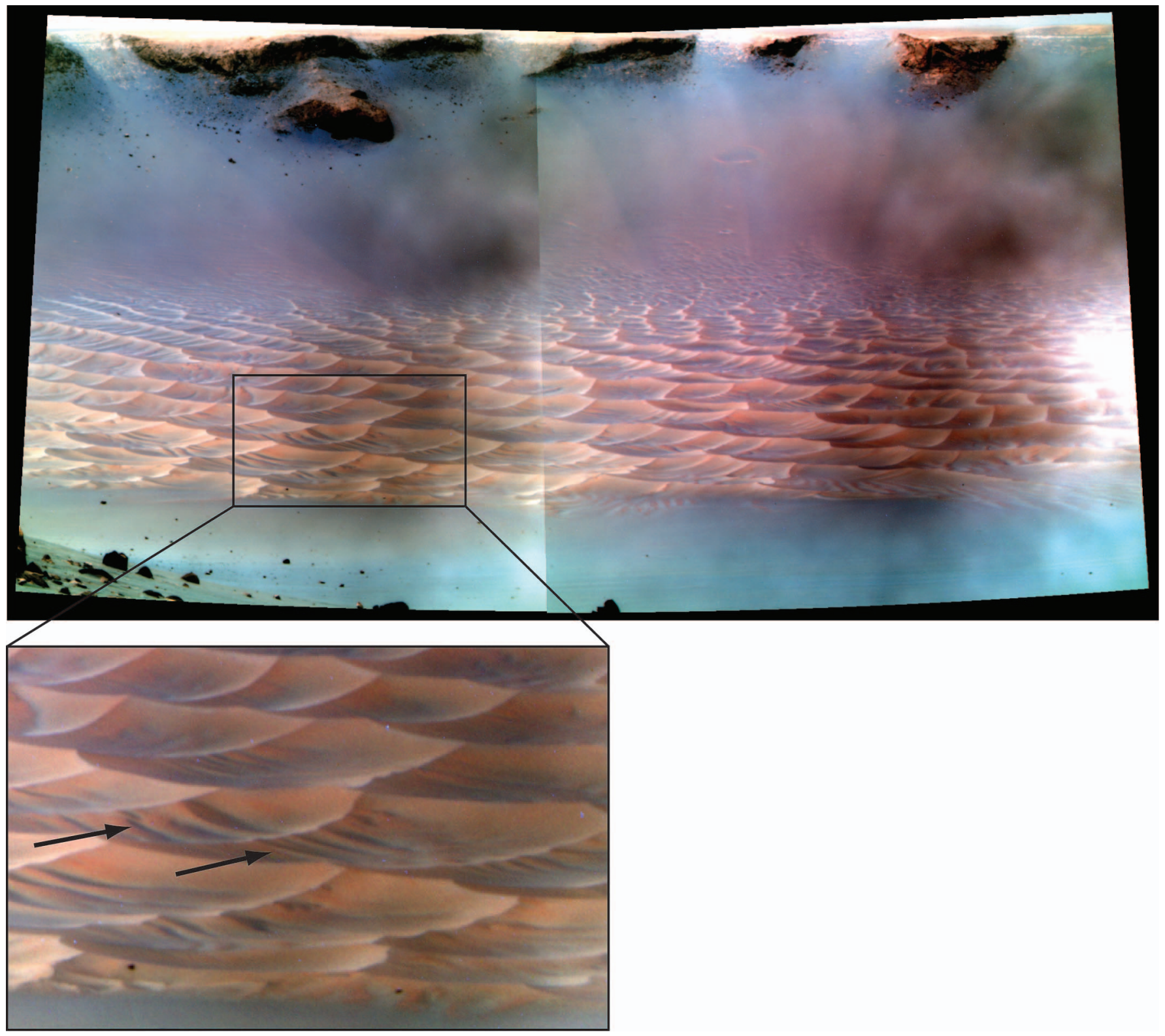

FIg. 12.-Modern dunes in the center of Victoria crater (Pancam false color image acquired on Sol 1437). Maximum dune heights range from 2 to $5 \mathrm{~m}$, as determined from a HiRISE DEM. Close-up image shows small superimposed dunes (black arrows) migrating across larger star dunes. While these superimposed dunes may be analogous to the ancient bedforms inferred at Duck Bay and Cape Verde, they are an order of magnitude smaller.

erosional contact below Steno. This surface is interpreted to represent the migration of dunes across a draa, and its orientation indicates that the draa was migrating from northwest to southeast at the time that the surface was formed. The stratal geometry above and below the erosional surface indicates dune migration in opposing directions or by southward migrating three-dimensional bedforms. Additionally, the presence of three orders of bedforms and a complex wind regime indicates that the strata may have been part of a large sand sea, with no evidence for aqueous deposition, as observed at Eagle and Endurance craters. Victoria crater not only reveals the regional extent of processes seen elsewhere in Meridiani Planum, but the greater size of its outcrop exposures reveals the building of ever-larger eolian bedforms.

\section{REFERENCES}

Amundson R, Ewing S, Dietrich W, Sutter B, Owen J, Chadwick O, Nishiizumi K, Walvoord M, McKay C. 2008. On the in situ aqueous alteration of soils on Mars. Geochimica Et Cosmochimica Acta 72:3845-3864.

Arvidson ER, Anderson RC, Haldemann AFC, Landis FA, Li R, Lindemann RA, Matijevic JR, Morris RV, Richter L, Squyres SW, Sullivan RJ, Snider NO. 2003. Physical properties and localization investigations associated with the 2003 Mars Exploration rovers. Journal of Geophysical Research-Planets 108, doi:10.1029/2002JE002041

Bell JF III, Squyres SW, Herkenhoff KE, Maki JN, Arneson HM, Brown D, Collins SA, Dingizian A, Elliot ST, Hagerott EC, Hayes AG, Johnson MJ, 
Johnson JR, Joseph J, Kinch K, Lemmon MT, Morris RV, Scherr L, Schwochert M, Shepard MK, Smith GH, Sohl-Dickstein JN, Sullivan RJ, Sullivan WT, Wadsworth M. 2003. Mars Exploration Rover Athena Panoramic Camera (Pancam) investigation. Journal of Geophysical Research-Planets 108, doi: 10.1029/2003JE002070

Bell JF III, Joseph J, Sohl-Dickstein JN, Arneson HM, Johnson MJ, Lemmon MT, Savransky D. 2006. In-flight calibration and performance of the Mars Exploration Rover Panoramic Camera (Pancam) instruments. Journal of Geophysical Research-Planets 111, doi:10.1029/2005JE002444

Fryberger SG. 1993. A review of aeolian bounding surfaces, with examples from the Permian Minnelusa Formation, USA. In North CP, Prosser DJ (Editors), Characterization of Fluvial and Aeolian Reservoirs: Geological Society of London. Special Publications 73, p. 167-197.

Gorevan SP, Myrick T, Davis K, Chau JJ, Bartlett P, Mukherjee S, Anderson R, Squyres SW, Arvidson RE, Madsen MB, Bertelsen P, Goetz W, Binau CS, Richter L. 2003. The Rock Abrasion Tool: Mars Exploration Rover Mission. Journal of Geophysical Research 108, doi:10.1029/2003JE002061

Grant JA, Wilson SA, Cohen BA, Golombek MP, Geissler PE, Sullivan RJ, Kirk RL, Parker TJ. 2008. Degradation of Victoria crater, Mars. Journal of Geophysical Research-Planets 113, doi:10.1029/2008JE003155

Grotzinger JP, Arvidson RE, Bell JF, Calvin W, Clark BC, Fike DA, Golombek M, Greeley R, Haldemann A, Herkenhoff KE, Jolliff BL, Knoll AH, Malin M, McLennan SM, Parker T, Soderblom L, Sohl-Dickstein JN, Squyres SW, Tosca NJ, Watters WA. 2005. Stratigraphy and sedimentology of a dry to wet eolian depositional system, Burns formation, Meridiani Planum, Mars. Earth and Planetary Science Letters 240:11-72.

Grotzinger J, Bell J, Herkenhoff K, Johnson J, Knoll A, McCartney E, McLennan S, Metz J, Moore J, Squyres SW, Sullivan R, Ahronson O, Arvidson R, Jolliff B, Golombek M, Lewis K, Parker T, Soderblom J. 2006. Sedimentary textures formed by aqueous processes, Erebus crater, Meridiani Planum, Mars. Geology 34:1085-1088.

Havholm KG, Kocurek G. 1988. A preliminary-study of the dynamics of a modern draa, Algodones, Southeastern California, USA. Sedimentology 35:649-669.

Hayes AG, Grotzinger JP, Edgar LA, Squyres SW, Watters WA, Sohl-Dickstein J. 2011. Reconstruction of eolian bedforms and paleocurrents from crossbedded strata at Victoria Crater, Meridiani Planum, Mars. Journal of Geophysical Research 116, doi:10.1029/2010JE003688

Herkenhoff KE, Squyres SW, Bell JF III, Maki JN, Arneson HM, Bertelsen P, Brown DI, Collins SA, Dingizian A, Elliott ST, Goetz W, Hagerott EC, Hayes AG, Johnson JM, Kirk RL, McLennan S, Morris RV, Scherr LM, Schwochert MA, Shiraishi LR, Smith GH, Soderblom LA, Sohl-Dickstein JN, Wadsworth MV. 2003. Athena Microscopic Imager investigation. Journal of Geophysical Research-Planets 108, doi:10.1029/2003JE002076

Hunter RE. 1977. Basic types of stratification in small eolian dunes. Sedimentology 24:361-387.

Knauth LP, Burt DM, Wohletz KH. 2005. Impact origin of sediments at the opportunity landing site on Mars. Nature 438:1123-1128.

Lewis KW, Aharonson O, Grotzinger JP, Squyres SW, Bell JF III, Crumpler LS, Schmidt M. 2008. Structure and stratigraphy of Home Plate from the Spirit Mars Exploration Rover. Journal of Geophysical Research-Planets 113, doi:10.1029/2007JE003025

McCollom TM, Hynek BM. 2005. A volcanic environment for bedrock diagenesis at Meridiani Planum on Mars. Nature 438:1129-1131.

McKee ED. 1966. Structure of dunes at White Sands National Monument, New Mexico. Sedimentology 7:1-61.

McLennan SM, Bell JF, Calvin WM, Christensen PR, Clark BC, de Souza PA, Farmer J, Farrand WH, Fike DA, Gellert R, Ghosh A, Glotch TD, Grotzinger JP, Hahn B, Herkenhoff KE, Hurowitz JA, Johnson JR, Johnson SS, Jolliff B, Klingelhofer G, Knoll AH, Learner Z, Malin MC, McSween HY, Pocock J, Ruff SW, Soderblom LA, Squyres SW, Tosca NJ, Watters WA, Wyatt MB, Yen A. 2005. Provenance and diagenesis of the evaporite-bearing Burns formation, Meridiani Planum, Mars. Earth and Planetary Science Letters 240:95-121.

McLennan SM, Grotzinger JP. 2008. The sedimentary rock cycle of Mars. In Bell JF III (Editor), The Martian Surface: Composition, Mineralogy, and Physical Properties: Cambridge University Press, UK, p. 541-577.

Metz JM, Grotzinger JP, Rubin DM, Lewis KW, Squyres SW, Bell JF III. 2009.
Sulfate-rich eolian and wet interdune deposits, Erebus Crater, Meridiani Planum, Mars. Journal of Sedimentary Research 79:247-264.

Mittlefehldt DW, Schröder C, Gellert R, Klingelhöfer G, Jolliff BL, Morris RV, and the Athena Science Team. 2008. Chemostratigraphy and Fe Mineralogy of the Victoria Crater Duck Bay Section: Opportunity APXS and Mössbauer Results. Lunar and Planetary Science, Abstract 2404.

Mountney N, Howell J, Flint S, Jerram D. 1999. Relating eolian boundingsurface geometries to the bed forms that generated them: Etjo Formation, Cretaceous, Namibia. Geology 27:159-162.

Paola C, Borgman L. 1991. Reconstructing random topography from preserved stratification. Sedimentology 38:553-565.

Rubin DM, Carter CL. 2005. Bedforms 4.0: MATLAB Code for Simulating Bedforms and Cross-Bedding: US Geological Survey Open-File Report 2005-1272.

Rubin DM, Hunter RE. 1982. Bedform climbing in theory and nature. Sedimentology 29:121-138.

Rubin DM, Hunter RE. 1983. Reconstructing bedform assemblages from compound cross-bedding. In Brookfield ME, Ahlbrandt TS (Editors). Eolian Sediments and Processes: Elsevier Science Publishing Company, New York, p. 407-428.

Squyres SW, Arvidson RE, Baumgartner ET, Bell JF, Christensen PR, Gorevan $\mathrm{S}$, Herkenhoff KE, Klingelhofer G, Madsen MB, Morris RV, Rieder R, Romero RA. 2003. Athena Mars rover science investigation. Journal of Geophysical Research-Planets 108, doi:10.1029/2003JE002121

Squyres SW, Arvidson RE, Bell JF, Bruckner J, Cabrol NA, Calvin W, Carr MH, Christensen PR, Clark BC, Crumpler L, Des Marais DJ, d'Uston C, Economou T, Farmer J, Farrand W, Folkner W, Golombek M, Gorevan S, Grant JA, Greeley R, Grotzinger J, Haskin L, Herkenhoff KE, Hviid S, Johnson J, Klingelhofer G, Knoll AH, Landis G, Lemmon M, Li R, Madsen MB, Malin MC, McLennan SM, McSween HY, Ming DW, Moersch J, Morris RV, Parker T, Rice JW, Richter L, Rieder R, Sims M, Smith M, Smith P, Soderblom LA, Sullivan R, Wanke H, Wdowiak T, Wolff M, Yen A. 2004a. The Opportunity Rover's Athena science investigation at Meridiani Planum, Mars. Science 306:1698-1703.

Squyres SW, Grotzinger JP, Arvidson RE, Bell JF, Calvin W, Christensen PR, Clark BC, Crisp JA, Farrand WH, Herkenhoff KE, Johnson JR, Klingelhofer G, Knoll AH, McLennan SM, McSween HY, Morris RV, Rice JW, Rieder R, Soderblom LA. 2004b. In situ evidence for an ancient aqueous environment at Meridiani Planum, Mars. Science 306:1709-1714.

Squyres SW, Aharonson O, Arvidson RE, Bell JF, Christensen PR, Clark BC, Crisp JA, Farrand W, Glotch T, Golombek MP, Grant J, Grotzinger J, Herkenhoff KE, Johnson JR, Jolliff BL, Knoll AH, McLennan SM, McSween HY, Moore JM, Rice JW, Tosca N. 2006. Bedrock formation at Meridiani Planum. Nature 443:E1-E2.

Squyres SW, Knoll AH, Arvidson RE, Ashley JW, Bell JF, Calvin WM, Christensen PR, Clark BC, Cohen BA, de Souza PA, Edgar L, Farrand WH, Fleischer I, Gellert R, Golombek MP, Grant J, Grotzinger J, Hayes A, Herkenhoff KE, Johnson JR, Jolliff B, Klingelhofer G, Knudson A, Li R, McCoy TJ, McLennan SM, Ming DW, Mittlefehldt DW, Morris RV, Rice JW, Schroder C, Sullivan RJ, Yen A, Yingst RA. 2009. Exploration of Victoria Crater by the Mars Rover Opportunity. Science 324:1058-1061.

Wilson IG. 1971. Desert sandflow basins and a model for development of ergs. Geographical Journal 137:180-199. 